\title{
Nama:Naura mutiara johan
}

\section{Kelas:HTN E}

\section{Nim:10200120194}

Konsepsi HakAsasi Manusia dan

Implementasinya di Indonesia

Bambang Sutiyoso

The issues ofhuman rights constitute the global issues recently that will not ignore with some reasons including in Indonesia. The concept of human rights and its realization in each state may not similar although actually the substance ofhuman rights is equal. In this respect there are three concepts and implementations of human right in the world that be regarded as the representatives of western states, Socialism -communism and Islamic doctrine. The consequence of human rights emerges human obligations, that both human rights and human obligations are parallel and a system. The ignoring one of them will raise heavy infraction of human rights itself. The Implementation of human rights in Indonesia particularly even though many cases emerge generally either development or the maintenance ofhuman rights seems the progress. In this sense, the regulating law ofhuman rights by legislating the rules and by establishing the Human Rights Court in overcoming many cases of heavy evading of raised human rights. Istilah hak-hak asasi manusia dalam apapun yang dapat mencabut hak itu dari beberapa bahasa asing dikenal dengan tanganpemiliknya. Demikianpulatidakada sebutan sebagai berikut: droit de Vhome seorangpun diperkenankan untuk (Perancis) yang berarti hak manusia, hu- merampasnya, serta tidak ada kekuasaan man right (Inggris) atau mensen rechten apapun yang boleh membelenggunya." (Belanda), yang dalam bahasa Indonesia Karena HAM itu bersifat kodrati, disalin menjadi hak-hak kemanusiaan atau sebenamya ia tidak memerlukan legitimasi hak-hak asasi manusia.^ yuridis untuk pemberlakuannya dalam Hak asasi manusia (HAM) pada suatu sistem hukum nasional maupun hakekatnya merupakan hak kodrati yang internasional. Sekalipun tidak ada secara inheren melekat dalam setiap diri perlindungan dan jaminan konstitusional manusia sejak lahir. Pengertian ini terhadap HAM, hak itu tetap eksis dalam 
mengandung arti bahwa HAM merupakan setiap diri manusia. Gagasan HAM yang kanmia Allah Yang Maha Pencipta kepada bersifat teistik ini diakui kebenarannya hamba-Nya. Mengingat HAM itu adalah sebagai nilai yang paling hakiki dalam karunia Allah, maka tidak ada badan kehidupan manusia. Namun karena sebagian besar tata kehidupan manusia bersifat sekuler dan positivistik, maka eksistensi HAM memerlukan landasan yuridis untuk diberlakukan dalam mengatur kehidupan manusia.^ Dalam perspektif sejarah hukum, setiap ada penyalahgunaan kekuasaan yang berimplikasi terhadap perampasan, perkosaan dan pemanipulasian HAM oleh manusia satu kepada manusia yang lain atau oleh penguasa kepada rakyatnya akan selalu muncul krisis kemanusiaan. Bahkan kemudian memunculkan formula-formula atau dokumen-dokumen resmi hak-hak asasi manusia atau sumber hukum yang memberi hak bagi rakyat. Misalnya dokumen Magna Charta di Inggris tahun 1215yang memberikan hak-hak bagi rakyat dan sekaligus membatasi kekuasaan raja. Kemudian dokumen The Virginia Bill of Rights dan declarations ofIndependence yang melahirkan kemerdekaan Amerika Serikat tahun 1776, yang berisi jaminan kebebasan individu terhadap kekuasaan negara. Begitu pula dokumen Declarations desDroites LUome etDu Cituyen di Francis tahun 1789 yang berprinsip bahwa 
manusia pada hakekatnya adalah balk dan

karenanya harus hidup bebas dan sama

kedudukannya dalam hukum. Di Rusia

tahun 1918, juga muncul suatu dokumen

yang meriyebut hak-hak dasar sosial, tetapi

hak-hak dasar individu tidak disebut sama

sekali. Selanjutnya dokumen Declarations

of Human Rights tahun 1948 yang

dikeluarkan oleh Perserikatan BangsaBangsa (PBB) yang menjamin hak-hak sipil, hak-hak sosial dan hak-hak kebebasan politik.

Secara filosofis berbagai dokumen hakhak asasi manusia tersebut terdapat

adanya perbedaan muatan nilai dan

orientasi. Di Inggris menekankan pada

pembatasan kekuasaan raja, di Amerika

Serikat mengutamakan kebebasan

individu, di Perancis memprioritaskan

egalitarianisme persamaan kedudukan di

hadapan hukum, di Rusia tidak

diperkenalkan hak individu tetapi hanya

mengakui hak sosial. Sementara iti^

Perserikatan Bangsa-Banpa merangkun^ berbagai nilai dan orientasi karen^^

Deklarasi Umum Hak Asasi Manusia di

badan dunia ini sebagai kesepakatan

berbagai negara setelah mengalami

revolusi Perang Dunia II, yang menelorkan

pengakuan prinsip kebebasan

perseorangan, kekuasaan hukum dan

demokrasi sebagaimana diformulasikan

dalam preambule Atlantik Charter 1945.'*|

Dokumen dan kesaksian sejarah

tersebut menunjukkan bahwa setiap teijadi 
krisis hak asasi manusia selalu muncuj

revolusi atau gejolak sosial. Seperti halnya

krisis hak asasi manusia di negara-negara

komunis tahun 1990 yang menghancurkan

tembok Berlin dan penghancuran patungj

patung tokoh mereka yang sebelumnya

dipuja-puja. Rangkaian kesaksian sejarah

tersebut menunjukkan bahwa hak asasi

manusia merupakan konstitusi kehidupan[

karena hak asasi manusia merupakan

prasyarat yang harus ada dalam setiap

kehidupan manusia dan merupakan beka)

bagi setiap insan untuk dapat hidup sesuai

fitrah kemanusiaannya. Perjuangan dan perkembangan hak-hak

asasi manusia di setiap negara mempunyai

latar belakang sejarah sendiri-sendiri

sesuai dengan peijalanan hidup bangsanya,

meskipun demikian sifat dan hakikat HAM

di mana-mana pada dasaraya adalah sama.

Dalam konteks itulah, tulisan berikut ini

akan mengungkapkan beberapa konsepsi

dan model pelaksanaan HAM, yaitu di

negara-negara Barat yang sebagian besar

menganut paham liberal kapitalis dan

negara-negara pengikut aliran komunissosialis serta konsepsi dan model HAM

menurut ajaran Islam. Ketiga sistem ini

dapat dianggap mewakili berbagai konsepsi

HAM yang ada, mengingat sebagian besar

dari mereka berkiblat dan mengacu salah

satu dari ketiga sistem tersebut. Selain itu

dikemukakan pula tentang HAM dan 
implementasinya di Indonesia, dengan

mengupas seputar perkembangan dan penegakkan HAM di Indonesia.

Konsepsi dan Model

Pelaksanaan HAM

Seperti diketahui, bahwa HAM itu

adalah bersifat universal. Namun demikian

pelaksanaan HAM tidak mungkin

disamaratakan antara satu negara dengan

negara yang lain. Masing-masing negara

tentu mempunyai perbedaan konteks

sosial, kultural maupun hukumnya. Di

samping itu pengalaman sejarah dan

perkembangan masyarakat sangat

mempengaruhi implementasi HAM

tersebut. Keuniversalan HAM dewasa ini

masih mengundang perdebatan dan

perbedaan dalam praktek penerapannya di

antara masing-masing anggota

Perserikatan Bangsa-Bangsa. Hal ini dapat

dilihat dalam perspektiffilsafat hukum atau

ideologi yang melatarbelakangi norma

hukum atau negara yang bersangkutan. Pengakuan dan potret pelaksanaan

HAM di negara komunis dapat dilihat dari

watak aturan hukumnya yang tidak

memberi tempat adanya hubungan hukum

privat, karena segala sesuatu dianggap dari

masyarakat dan untuk kepentingan

masyarakat. Semua hukum menjadi

administrasi kebijakan penguasa, karena

itu hukum harus mengabdi pada politik 
partai. Demikian pula pengadilan harus

tunduk pada pengawasan kekuasaan

poliitik partai. Kondisi demikian antara lain

tergambar dalam buku The Gulag Archi

pelago, karangan Alexander Solshenitsyn

yang melukiskan tentang pelecehan HAM

di Rusia, hukum sebagai alat kekuasaan dan

pengadilan dilakukan dibelakang pintu

tertutup. Hal serupa juga terjadi pada

Fascis dan Nazi yang menonjolkan

despotisme, dalam diri negara merupakan

hukum, yaitu legitimasi nafsu penguasa

untuk menguasai dan mendominasi hak

asasi rakyat. Sedangkan konsepsi dan

pemberlakuan HAM di negara liberal

kapitalis dapat dilihat dari karakter aturan

hukumnya yang berakar pada filsafat

individualisme-utilitarian. Tujuan filsafat

ini adalah emansipasi individu dan

orientasinya adalah menambah

kesenangan individu. Hukum yang

dianggap baik adalah hukum yang

memanjakan kebebasan bagi setiap

individu dan memacu agar setiap individu

mengejar apa yang dianggap baik bagi

dirinya. Falsafah ini pula yang menjadi akar

dari prinsip "Laissez Faire" dalam dunia

perekonomian dewasa ini. Perekonomian

dunia didorong mengarah pada mekanisme

persaingan bebas yang diyakini akan

menghasilkan kebahagiaan yang maksimal 
bagi setiap individu.^

Terhadap konsepsi dan praktek-praktek

di atas, seorang filosof muslim, Dr.

Mohammad Iqbal (1873-1938)

sebagaimana dikutip Moh. Natsir pernah

mengemukakan bahwa baik kapitalisme

Barat dan sosialisme Mams, pada asasnya

berdasarklan nilai-riilai kebendaan dari

kehidupan serta kosong dari warisan

ruhaniyah."Sosialisme Karl Marx sebagai

suatu rencana yang berdasarkan kesamaah

perut (equality of stomach) dan bukan

kesamaah nih. Demikian juga kapitalisme;

imperialisme,- • kolonialisme dan

rasionalisme dilukiskan' sebagai

kegemukah jasad. ${ }^{\circledR}$

Pada saat yang sama, sudah masanya

PBB sebagai badan dunia mengevaluasi

konsep dasar HAM yang dipakainya serta

praktek pelaksanaannya agar eksistensi

keberadaannya tidak kehilangan relevansi

sosio humanisnya. Konsep HAM- PBB yang

hanya menonjolkan' hak. dan tanpa

kewajiban asasi, perlu dipertanyakan

secara kritis dalam hubungannya dengan

banyaknya benturan dan konflik HAM yang

banyakmemakan korbanjiwadan martabat

manusia, baik secara sistemik misalnya

agresi suatu negara terhadap negara lain,

maupun secara evolutif misalnya

munculnya euthanasia, aborsi dan lain 
sejenisnya.

Konsep - dan prototipe realisasi

kewajiban asasi dan HAM yang dilandasi

nilai-nilai yang -sempurna telah

dicontohkan secara faktual oleh segala

bangsa di 'dunia, yaitu setiap tanggal lo

Dzulhijjah di kota Makkah atau saat

pelaksanaan ibadah haji. Di mana segala

bangsa di dunia berkumpul dengan tujuanyang sama, pakaian yang sama, merasa

berkedudukan yang sama dan hanya

tunduk kepada kekuasaan AllahYangMaha

Esa. Namun tampaknya PBB telum rela

secara resmi untuk menarik kesimpulan

dan mengambil esensi konsep yang

mendasari konstruksi hubungan

kemamisiaan'dan sosial yang harmonis di

kota Makkah itu. Sebenarnya yang perlu ditelaal

sekarang oleh masyarakat dan bangsa

bangsa di dunia kareria konsepsi dan fakta

fakta pelaksanaannya terbukti merupakanperwujudan dari -^'suatu konstitusi.

kehidupan manusia yang diajarkan daii'

dicontohkan oleh seorang pemimpin

masyarakat bangsa, pembela dam

pengangkat martabat manusia, yaitu Nabi

Muhammad SAW (571-633). Arah dan dan

landasan pembinaan martabat dan hak-haK*

kemanusiaannya mempunyai kejelasaij

serta keharmonisan antara kewajiban asasi

dan'hak asasi, antara hak individu dan ha^

masyarakat. Lebih dari itu, karena

berdasarkan kepastian rohani yang mampu 
memahami tujuan hidup manusia^ yaitu pengabdian kepada AUah SWT. Bertitik tolak- dari konsepsi IMam tersebut pulalahTebih jauh Dr. Mohammad lqbal mengemukakan bahwa Islam pada hakekatnya adalah ta'uhid. Inti dari tauhid adalah working idea dan cita yang fa'al inilah membuahkan Keesaan dan kemerdekaan. Islam memberikan beberapa asas nyata seperti demokrasi dan kemerdekaan. Kemerdekaan pikiran dan menyatakan pendapat, kemerdekaan beragama, keesaan, 'toleransi,.keadilan sosial dan lain sebagainya. Bersamaan' dengan hak-hak manusia yang asasi ini, Is lam juga menetapkan beberapa kewajiban manusia yang asasi' untuk-mencapai kesejahteraa'n hidup berjamaah bagi seluruh umat manusia. ${ }^{\wedge} \mathrm{j}$ Seorang gurubesar hukumdari Monasfi University, bern'araa Christopher G. Weermantry, dalam seminar ihternasional tentang HAM di Jenewa bulan Desember 1988, • seperti dikutip Marjonp Reksodiputro, ${ }^{\circledR}$ secara jujur mengatakan:' "Ajaran Islam datang jauh lebih dahulju daripada negara Barat, yang inti ajarannyja tentang HAM menyatakan bahwa bahwa hak-hak dasar tidak dapat dicabut dan para penguasa melaksanakan kekuasaanya atas dasar kepercayaan dan hanya sepanjang kehormatan penguasa itu benar. Prinsipprinsip ini merupakan inti dari teori politik Islam, di mana enam ratus tahun sebelum 
John Locke mengemukakan teorinya di Barat". .

Kesadaran untuk menegakkan HAM, sebagaimana diisyaratkan dalam Islam bahwa mempeijuangkan dan menikmati hak asasi adalah-merupakan kewajiban yang suci, seperti ditegaskan dalam AlQur'an Surat Al-Qashash: 77 yang artinya:

"Dan carilah pada apa yang telah dianugerahkan Allah kepadamu (kebahagiaan) negeri Akherat, dan janganlah kamu melupakan kebahagiaan (kenlkmatan, hak-hak) duniawi dan berbuat baiklah (kepada orang lain), sebagaimana Allah telah berbuat baik kepadamu, dan janganlah kamu berbuat kerusakan di muka bumi. Sesungguhnya Allah tidak menyukai orang-orang yang berbuat kerusakan". Di samping itu masih banyak ayat-ayat lain yang mengungkapkan perlunya menegakkan HAM dan martabatnya, seperti yang tertcantum dalam Q.S. Asy-Syura: 39, QS.

Ali Imran ; 171, QS. An-Nahl: 110, QS. AnNisa : 97, QS. Ali Imran: 135,'QS. An-Nisa : 107 dan sebagainya.

Hak asasi dalam perspektif Islam, terdapat dalam setiap sektor kehidupan, serta memiliki posisi strategis dalam menegakkan dan meningkatkan kualitas kemanusiaan. Bahkan interrelasi antara hak asasi dan kewajiban asasi antara lain dapat ditunjukkan mempunyai nilai 
keutamaan akhlak, apabila dilakukan dengan cara menegakkan keadilan atau menyampaikan perkataan yang benar di hadapan penguasa yang menyeleweng. Dalam hubungan ini terlihat bahwa proses penegakkan hukum dan keadilan menuntut adanya spirit amar ma'rufnahi munkar.. Nilai kejuangan dalam penegakkan hukum dan keadilan, antara lain karena di dalamnya banyak godaan dan tantangan serta menuntut pengorbanan serta keikhlasan sikap dalam rangka melindungi hak asasi manusia.^

' Kewajiban asasi manusia menjadi prasyarat utama agar dalam menjalankan hidup dan kehidupannya memiliki keseimbangan dan ketenangan jiwa serta menjadikan hidupnya bermakna bagi dirinya sendiri, keluarganya, lingkungannya serta masa depannya. Hubungan erat antara kewajiban asasi dan hak asasi, menunjukkan adanya kesempatan pemberian bagi individu dalam sikapnya, masyarakat dalam tradisinya, negara atau kelompok negara dalam budaya hukumnya. Hubungan etis antara kewajiban asasi dengan hak asasi, menuntut konsistensi sikap agar seseorang, masyarakat atau bangsa tidak berat sebelah dalam melakukan peran diri dan hubungan 
sosialnya,karena pada dasamya seseorang, .

masyarakat atau bangsa tidak dapat hidup

dengan baik dan benar, kalau hanya

melakukan atau menuntut hak asasinya

saja tanpa melakukan kewajiban asasi

secara seimbang. Bahkan dalam konsepsi

Islam, kewajiban asasi menjadi keutamaan

moral untuk didahulukan dibandingkan

dengan hak asasi itu sendiri.

Perkembangan HAM

di Indonesia

Berbeda dengan Inggris dan Perancis

yang mengawalisejarah perkembangan dan

peijuangan hak asasi manusianya dengan

menampilkan sosok pertentangan

kepentingan antara kaum bangsawan dan

rajanya yang lebih banyak mewakili

kepentingan lapisan atas atau golongan

tertentu saja. Peijuangan hak-hak asasi manusia Indonesia mencerminkan bentuk

pertentangan kepentingan yang lebih

besar, dapat dikatakan teijadi sejak masuk

dan bercokolnya bangsa asing di Indone

sia dalam jangka waktu yang lama.

Sehingga timbul berbagai perlawanan dari

rakyat untuk mengusir penjajah.

Dengan demikian sifat perjuangan

dalam mewujudkan tegaknya HAM di In

donesia itu tidak bisa dilihat sebagai

pertentangan yang hanya mewakili

kepentingan suatu golongan tertentu saja,

melainkan menyangkut kepentingan 
bangsa Indonesia secara utuh. Hal ini tidak berarti bahwa sebelum bangsa Indonesia mengalami masa penjajahan bangsa asing, tidak pernah mengalami gejolak berupa timbulnya penindasan manusia atas manusia. Pertentangan kepentingan manusia dengan segala atributnya (sebagai raja, penguasa, bangsawan, pembesar dan seterusnya) akan selalu ada dan timbul tenggelam sejalan dengan perkembangan peradaban manusia. Hanya saja di bumi Nusantara warna pertentanganpertentangan yang ada tidak begitu menonjol dalam panggung sejarah, bahkan sebalilmya dalam catatan sejarah yang ada' berupa kejayaan bangsa Indonesia ketika berhasil dipersatukan di bawah panji-panji kebesaran Sriwijaya pada abad VII hingga pertengahan abad IX, dan kerajaan Majapahit sekitar abad XII hingga permulaan abad XVI. ${ }^{10}$ Diskursus tentang HAM memasuki babakan baru, pada saat Badan Penyelidik Usaha Persiapan Kemerdekaan Indonesia (BPUPKI) yang bertugas menyiapkan rancangan UUD pada tahun 1945, dalam pembahasan-pembahasan tentang sebuah konstitusi bagi negara yang akan segera merdeka, silang selisih tentang perumusan HAM sesungguhnya telah muncul. Di sana terjadi perbedaan antara Soekarno dan Soepomo di satu pihak dan Mohammad Hatta dan Mohammad Yamin di pihak lain. 
Pihak yang pertama meriblak

dimasukkannya HAM terutama yang

bersifat individual ke dalam UUD karena

menunit mereka Indonesia hams dibangun

sebagai negara kekeluargaan. Sedangkan

pihak kedua menghendaki agar UUD itu

memuat masalah-masalah HAM secara

eksplisit."

Sehari setelah proklamasi

kemerdekaan, tanggal 18 Agustus 1945

Panitia Persiapan Kemerdekaan Indonesia

(PPKI) mengadakan sidang untuk

mengesahkan UUD 1945 sebagai UUD

negara Republik Indonesia. Dengan

demikian terwujudlah perangkat hukum

yang di dalamnya memuat hak-hak dasar

manusia Indonesia serta kewajibankewajiban yang bersifat dasar pula. Seperti

yang tertuang dalam Pembukaan,

pernyataan mengenai hak-hak asasi

manusia tidak mendahulukan hak-hak asasi

individu, melainkan pengakuan atas hak

yang bersifat umum, yaitu hak bangsa. Hal

ini seirama dengan latar belakang

peijuangan hak-hak asasi manusia Indone

sia, yang bersifat kebangsaan dan bukan

bersifat individu." Sedangkan istilah atau

perkataan hak asasi manusia itu sendiri

sebenarnya tidak dijumpai dalam UUD

1945 baik dalam pembukaan, batang

tubuh, maupun penjelasannya. Istilah

yang dapat ditemukan adalah pencantuman 
dengan tegas perkataan hak dan kewajiban

warga negara, dan hak-hak Dewan

Perwakilan Ra|^at. Bam setelah UUD 1945

mengalami perubahan atau amandemen kedua, istilah hak asasi manusia

dicantumkan secara tegas. ${ }^{\prime \wedge}$

Dalam sejarah ketatanegaraan Indone

sia pernah mengalami perubahan

konstitusi dari UUD 1945 menjadi

konstitusi RIS (1949), yang di dalamnya

memuat ketentuan hak-hak asasi manusia

yang tercantum dalam Pasal 7 sampai

dengan 33. Sedangkan setelah konstitusi

RIS berubah menjadi UUDS C1950),

ketentuan mengenai hak-hak asasi manusia

dimuat dalam Pasal 7 sampai dengan 34.

Kedua konstitusi yang disebut terakhir

dirancang oleh Soepomo yang muatan hak

asasinya banyak mencontoh Piagam Hak

Asasi yang dihasilkan oleh Perserikatan

Bangsa-Bangsa, yaitu The Universal Dec

laration ofhuman Rights tahun 1948 yang

berisikan 30 Pasal."*

Dengan Dekrit Presiden RI tanggal 5 juli

1959, maka UUD 1945 dinyatakan berlaku

lagi dan UUDS 1950 dinyatakan tidak

berlaku. Hal ini berarti ketentuanketentuan yang mengatur hak-hak asasi

manusia Indonesia yang berlaku adalah

sebagaimana yang tercantum dalam UUD

1945- Pemahaman atas hak-hak asasi

manusia antara tahun 1959 hingga tahun

1965 menjadi amat terbatas karena 
pelaksanaan UUD 1945 dikaitkan dengan

paham NASAKOM yang membuang paham

yang berbau Barat. Dalam masa Orde Lama

ini banyak terjadi penyimpanganpenyimpangan terhadap Pancasila dan

UUD 1945 yang suasananya diliputi penuh

pertentangan antara golongan politik dan

puncaknya terjadi pemberontakan G-30-

S/PKI tahun 1965. Hal ini mendorong

lahirnya Orde Baru tahun 1966 sebagai

koreksi terhadap Orde Lama. Dalam awal

masa Orde Baru pernah diusahakan untuk menelaah kembali masalah HAM, yang

melahirkan sebuah rancangan Ketetapan

MPRS, yaitu berupa rancangan Pimpinan

MPRS RI No. A3/I/Ad Hoc B/MPRS/1966,

yang terdiri dari Mukadimah dan 31 Pasal

tentang HAM. Namun rancangan ini tidak

berhasil disepakati menjadi suatu

ketetapan.'5

Kemudian di dalam pidato kenegaraan

Presiden RI pada pertengahan bulan

Agustus 1990, dinyatakan bahwa rujukan

Indonesia mengenai HAM adalah sila

kedua Pancasila "Kemanusiaan Yang Adil

dan Beradab" dalam kesatuan dengan silasila Pancasila lainnya. Secara historis

pernyataan Presiden mengenai HAM

tersebut amat penting, karena sejak saat

itu secara ideologis, politis dan konseptual

HAM dipahami sebagai suatu implementasi

dari sila-sila Pancasila yang merupakan

dasar negara dan pandangan hidup bangsa

Indonesia. Meskipun demikian, secara 
Ideologis, politis dan konseptual, sila kedua tersebut agak diabaikan sebagai sila yang mengatur HAM, karena konsep HAM dianggap berasal dari paham individualisme dan liberalisme yang secara ideologis tidak diterima. ${ }^{*}$ Perkembangan selanjutnya adalah dengan dibentuknya Komisi Nasional Hak Asasi Manusia (KOMNAS HAM) berdasarkan Keputusan Presiden RI No. 50 Tahun 1993 tanggal 7 Juni 1993.

Pembentukan KOMNAS HAM tersebut pada saat bangsa Indonesia sedang giat melaksanakan pembangunan, menunjukkan keterkaitan yang erat antara penegakkan HAM di satu pihak dan penegakkan hukum di pihak lainnya. Hal ini senada dengan deklarasi PBB tahun 1986, yang menyatakan HAM merupakan tujuan sekaligus sarana pembangunan. Keikutsertaan $\mathrm{ral}^{\wedge}$ at dalam pembangunan bukan sekedar aspirasi, melainkan kunci keselunihan hak asasi atas pembangunan itu sendiri. Hal tersebut menjadi tugas badan-badan pembangunan internasional dan nasional untuk menempatkan HAM sebagai fokus pembangunan*^ Guna lebih memantapkan perhatian atas perkembangan HAM di Indonesia, oleh berbagai kalangan masyarakat (organisasi maupun lembaga), telah diusulkan agar dapat diterbitkannya suatu Ketetapan MPR 
yang memuat piagam hak-hak asasi'

Manusia atau Ketetapan MPR tentang

GBHN yang di dalamnya memuat

operasionalisasi daripada hak-hak dan

kewajiban-kewajiban asasi manusia Indo

nesia yang ada dalam UUD 1945.

Akhirnya ketetapan MPR RI yang

diharapkan memuat secara adanya HAM

itu dapat diwujudkan dalam masa Orde

Reformasi, yaitu selama Sidang Istimewa

MPR yang berlangsung dari tanggal 10

sampai dengan 13 November 1988. Dalam

rapat paripurna ke-4 tanggal 13 Novem

ber 1988, telah diputuskan lahirnya

Ketetapan MPR RI No. XVII/MPR/1988

tentang Hak Asasi Manusia. Kemudian

Ketetapan MPRtersebut menjadi salah satu

acuan dasar bagi lahirnya UUNo. 39 Tahun

1999 tentang Hak Asasi Manusia yang

disahkan pada tanggal 23 September

1999.*® Undang-Undang ini kemudian

diikuti lahirnya Perpu No. 1 Tahun 1999

yang kemudian disempurnakan danditetapkan menjadi UU No. 26 Tahun 2000

tentang Penga(^an Hak Asasi Manusia.

Sebagai bagian dari HAM, sebelumnya

telah pula lahir UU No. 9 Tahun 1998

tentang 'Kemerdekaan Menyampaikan

Pendapat Di Muka Umum yang disahkan

dan diundangkan di Jakarta pada tanggal

26 oktober 1998, serta dimuat dalam LNRI

Tahun 1999 No. 165 Di samping itu, Indonesia telah 
meratifikasi pula beberapa konvensi

internasional yang mengatur HAM, antara

lain:*'

a. Deklarasi tentang Perlindungan dan

Penyiksaan, melalui UU No. 5 Tahun

1998.

b. Konvensi mengenai Hak Politik Wanita

1979, melalui UU No. 68 Tahun 1958.

c. Konvensi Pe.nghapusan Segala Bentuk

Diskriminasi Terhadap wanita, melalui

UU No. 7 Tahun 1984.

d. Konvensi Perlindungan Hak-Hak Anak, melalui Keppres No. 36 Tahun 1990.

e. Konvensi tentang Ketenagakerjaan, melalui UU No. 25 Tahun 1997, yang

pelaksanaannya ditangguhkan

sementara.

f. Konvensi tentang Penghapusan Bentuk

Diskriminasi Ras Tahun 1999, melalui

UU No. 29 Tahun 1999.

Penegakan HAM di Indonesia

Tegaknya HAM selalu mempunyai

hubungan korelasional positif dengan

tegaknya negara hukum. Dengan

dibentuknya KOMNAS HAM dan

Pengadilan HAM, regulasi hukum HAM

dengan ditetapkannya UU No. 39 Tahun

1999 dan UU No. 26 Tahun 2000 serta

dipilihnya para hakim ad hoc, akan lebih

menyegarkan iklim penegakkan hukum

yang sehat. Artinya kebenaran hukum dan 
keadilan hams dapat dinikmati oleh setiap warganegara secara egaliter. Disadari atau tidak, dengan adanya political will dari pemerintah terhadap penegakkan HAM, hal itu akan berimplikasi terhadap budaya politik yang lebih sehat dan proses demokratisasi yang lebih cerah. Harus disadari pula bahwa kebutuhan terhadap tegaknya HAM dan keadiiah itu memang memerlukan proses dan tuntutan konsistensi politik. Begitu pula keberadaan budaya hukum dari aparat pemerintah dan tokoh masyarakat merupakan faktor penentu (determinant) yang mendukung tegaknya HAM.

Kenyataan meniinjukkan bahwa masalah HAM di Indonesia selalu menjadi sorotan tajam dan bahan perbincangan terus-menerus, baik karena konsep dasarnya yang bersumber dari UUD 1945 maupun dalam realita praktisnya di lapangan ditengarai penuh dengan pelanggaran-pelanggaran. Sebab-sebab pelanggaran HAM antara lain adanya arogansi kewenangan dan kekuasaan yang dimiliki seorang pejabat yang berkuasa, yang mengakibatkan sulit mengendalikan dirinya sendiri sehingga teijadi pelanggaran terhadap hak-hak orang lain. $=^{\circ}$ Terutama dalam kurun waktu sepuluh tahun terakhir ini, masalah HAM di Indo nesia bergerak dengan cepat dan dalam 
jumlah yang sangat mencolok. Gerak yang

cepat tersebut terutama karena memang

telah teijadi begitu banyak pelanggaran

HAM, mulai dari yang sederhana sampai

pada pelanggaran HAM berat (gross hu

man right violation). Di samping itu juga

karena gigihnya organisasi-organisasi

masyarakat dalam memperjuangkan

pemajuan dan perlindungan HAM. ${ }^{\circledR 1}$

Pelanggaran HAM yang berat menurut

Pasal 7 UU No. 26 Tahun 2000 meliputi

kejahatan genocide (the crime ofgenocide)

dan kejahatan terhadap kemanusiaan

(crime against humanity). Kejahatan

genosida adalah setiap perbuatan yang

dilakukan dengan maksud untuk

menghancurkan atau memusnahkan

seluruh atau sebagian kelompok bangsa, ras, kelompok etnis kelompok agama,

dengan cara: a. membunuh anggota

kelompok; b. mengakibatkan penderitaan

fisik atau mental yang berat terhadap

anggota-anggota kelompok; c.

menciptakan kondisi kehidupan kelompok

yang akan mengakibatkan kemusnahan

secara fisik baik seluruh atau sebagiannya;

d. memaksakan tindakan-tindakan yang

bertujuan mencegah kelahiran di dalam

kelompok; e. memindahkan secara paksa

anak-anak dari kelompok tertentu ke

kelompok lain. ${ }^{\circledR}$ Sedangkan kejahatan

terhadap kemanusiaan adalah salah satu 
perbuatan yang dilakukan sebagai bagian

dari serangan yang meluas atau sistematik

yang diketahuinya bahwa serangan

tersebut ditujukan secara langsung

terhadap penduduk sipil berupa

pembunuhan, pemusnahan, perbudakan,

pengusiran, perampasan kemerdekaan,

penyiksaan, perkosaan, penganiayaan,

penghilangan orang secara paksa dan

kejahatan apartheid. ${ }^{\circledR \wedge}$

Seperti diketahui, di Indonesia telah

teijadi banyak kasus yang diindikasikan

sebagai pelanggaran'HAM berat, terutama

kasus kekerasan struktural yang

melibatkan aparat negara (polisi dan

militer) dengan akibat jatuhnya korban

dari kalangan penduduk sipil. Di antara

sederetan kasus yang mendapat sorotan

tajam dunia internasional, adalah kasus

DOM di Aceh, Tanjung Priuk, Timor-Timur

pasca jajak pendapat, tragedi Santa Cruz,

Liquisa, Semanggi danTrisakti. Pelanggaranpelanggaran tersebut dinilai cukup serius

dan bukanlah sebagai kejahatan biasa,

tetapi merupakan kejahatan terhadap

kemanusiaan (crime against humanity). ${ }^{\circledR \wedge}$ Munculnya berbagai kasus pelanggaran

HAM berat telah melahirkan kesadaran

kolektif tentang perlunya perlindungan

HAM melalui instnimen hukum dan kineija

institusi penegakhukumnya. Banyak kasuskasus pelanggaran HAM berat atau yang

mengandung unsur adanya pelanggaran

HAM yang selama ini tidak tersentuh oleh 
hukum, sebagai akibat dari bergulirnya

reformasi secara perlahan tapi pasti mulai diajukan ke lembaga peradilan. Lembaga peradilan, dalam hal ini Pengadilan HAM, merupakan forum paling tepat untuk membuktikan kebenaran tuduhan-tuduhan adanya pelanggaran HAM di Indonesia. Pasal 104 ayat (1) UU No. 39 Tahun 1999 secara tegas menyatakan bahwa untuk mengadili pelanggaran HAM yang berat dibentuk Pengadilan HAM di lingkungan Peradilan Umum. Hukum acara yang berlaku atas perkara pelanggaran HAM yang berat menurut Pasal 10 UU No. 26 Tahun 2000, dilakukan berdasarkan ketentuan hukum acara pidana, kecuali ditentukan lain dalam Undang-Undang ini. Dibentuknya Pengadilan HAM di Indo nesia patut disambut gembira, karena diharapkan dapat meningkatkan citra baik Indonesia di mata internasional, bahwa Indonesia mempunyai komitmen dan po litical will untuk menyelesaikan berbagai kasus pelanggaran HAM berat. Seiring dengan itu upaya penegakkan HAM di In donesia diharapkan mengalami peningkatan yang cukup signifikan. Kesimpulan HAM adalah persoalan yang bersifat universal, tetapi sekaligusjuga kontekstual. Setiap negara mempunyai sejarah peijuangan dan perkembangan HAM yang 
berbeda, oleh karena itu ko.nsepsi dan

implementasi HAM dari suatu negara tidak

dapat disamaratakan. Adanya HAM

menimbulkan konsekwensi • adanya

kewajiban asasi, keduanya beijalan secara

paralel dan merupakan satu kesatuan yang tak dapat dipisahkan. Pengabaian salah

satunya akan menimbulkan pelanggaran

HAM, dan Islam telah memberikan

pedoman yang sangat jelas mengenai

masalah ini.

Perkembangan dan peijuangan dalam

mewujudkan tegaknya HAM di Indonesia

terutama terjadi setelah adanya

perlawanan terhadap penjajahan bangsa

asing, sehingga tidak bisa dilihat sebagai

pertentangan yang hanya mewakili

kepentingan suatu golongan tertentu saja,

melainkan menyangkut kepentingan

bangsa Indonesia secara utuh.

Dewasa ini, meskipun ditengarai banyak

kasus pelanggaran HAM berat di Indone

sia, tetapi secara umum Implementasi

HAM di Indonesia, baik menyangkut

perkembangan dan penegakkannya mulai

menampakkan tanda-tanda kemajuan. Hal

ini terlihat dengan adanya regulasi hukum

HAM melalui peraturan perundangundangan. Di samping itu telah

dibentuknya Pengadilan HAM dalam upaya

menyelesaikan berbagai kasus pelanggaran

HAM berat yang terjadi. 